\title{
Studying and analysing the frequency and extent of damage to road safety barriers
}

\author{
Eukasz Jeliński ${ }^{1, *}$, and Kazimierz Jamroz ${ }^{1}$ \\ ${ }^{1}$ Faculty of Civil and Environmental Engineering, Gdansk University of Technology, 11 Narutowicza \\ str., 80-233 Gdansk, Poland
}

\begin{abstract}
The purpose of road safety barriers is to protect road users from the risk of injury or death and ensure the safety of people and structures within the roadside. When hit by a vehicle, safety barriers suffer damage. Most of the damage significantly affects the functionality and maintenance costs of the devices. Research under the LifeRoSE project aims to identify the distribution of the frequency and extent of safety barrier damage. The paper presents a test site, proposed research methodology, preliminary (based on a partial dataset) distribution of the frequency and extent of damage to safety barriers and factors that have the biggest effect on the frequency and extent of damage.
\end{abstract}

\section{Introduction}

A Run-Off-Road (ROR) crashes are still a frequent undesired event on non-urban roads. When they leave the road, vehicles roll over, intrude into areas directly adjacent to the road (pavement, public facilities, opposing lane), crash into roadside objects (trees, utility poles, embankments) or safety barriers. Run-off-road accidents represent more than $25 \%$ of rural accidents which lead to $30 \%$ of fatalities [1]. Previous analyses show [2,3] that when a vehicle runs off the road on one of Poland's express roads and motorways they will mostly hit a safety device (road safety barriers, energy absorbers, passive support structures).

Road safety devices must meet the requirements of durability and ensure a number of functional features such as safety, reliability, durability, effectiveness, etc. [4].

Safety management is a process which uses hazard analysis and risk assessment. Hazards are a potential source of damage or a circumstance that may generate consequences. A dangerous incident is likely to have consequences (injury, loss of health, loss of property or damage to the environment). Risk R (technical) is a combination of frequency or probability $\mathrm{P}$ of a dangerous incident and its consequences, i.e. in the form of damage (loss) K. The purpose of risk assessment is to determine risk measures quantitatively or define the level of the risk qualitatively or quantitatively [5].

The general risk measure takes this form:

$$
R=P \cdot K
$$

\footnotetext{
* Corresponding author: lukjelin@pg.edu.pl
} 
where:

$R$ - risk,

$P$ - probability of a dangerous incident,

$K$ - consequences (damage, loss) as a result of a dangerous incident.

Methods of safety hazard risk management are used to support decisions when road infrastructure is planned, designed, built and maintained. While safety barriers are an important road safety device and protect road users from the consequences of dangerous incidents, they may cause damage when a vehicle crashes into a barrier [6]. The safety of barriers is measured with the number of victims, density of accidents and costs of accidents. Safety can also be measured with the costs of safety barriers that are incurred when a vehicle hits a barrier. The costs are largely dependent on the type of barrier, frequency (probability) of a vehicle hitting the barrier and the length of the damaged barrier when an accident occurs. The probability of barrier damage depends on barrier reliability.

The reliability of a technical object is its ability to continue to perform specific functions under specific conditions and within a specific time (PN-EN 60300-1:2015). The reliability theory is based on the probability theory which is concerned with studying and forecasting random events. The purpose of reliability studies and analyses is to find a function to describe the probability of damage depending on time. It may have this general form [7]:

$$
P_{f}(t)=1-\Phi(\beta)
$$

where:

$P_{f}$ - probability of damage,

$\beta-$ reliability index,

$\Phi$ - cumulative distribution function (function determining the probability distribution).

In the case of safety barriers the basics of the reliability theory can be used to describe the frequency of unwanted events, i.e. vehicles crashing into barriers. The reliability function defines the probability of damage to individual elements of a vehicle restraint system. The reliability of road safety barriers can be measured with the amount of damage, intensity of damage and the time between barrier repairs.

A key feature of safety barriers is durability which defines the safety device's ability to maintain the original features as requested by the investor over a specific time and under specific operating and environmental conditions. Durability is defined as the ability of a device to remain operational over a specific time. In the case of safety barriers this means being able to withstand a crash as designed by the manufacturer [4].

Economic efficiency is that feature of a system which ensures that products which the system produces (such as safety barriers) are made with minimum inefficiency and waste (cost minimisation) but still achieve the desired outcome. Economic efficiency of road safety devices is best measured with cost indicators such as the cost to build a device, replace it and remove it (economic costs) and the return on costs incurred [8].
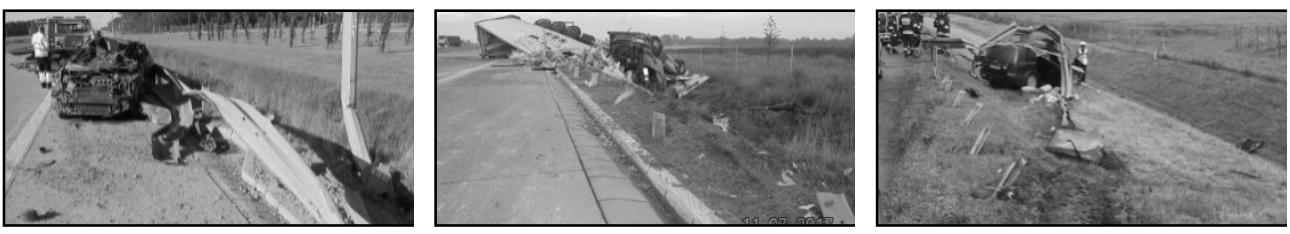

Fig. 1. Examples of damage to safety barriers and the consequences as a result of a vehicle crash. Source: General Directorate for National Roads and Motorways, national roads branches. 
To be safe, road barriers must meet the requirements of the PN-EN 1317 standard [9]. The document defines crash test criteria and methods for testing road restraint systems and describes classes of safety barriers by defining their functional features (level of containment, working width, crash intensity level, vehicle intrusion, dynamic deflection). Restraint system parameters are established in crash tests which are also required for licensing. The tests help to assess the damage and its parameters and the behaviour of the vehicle and barrier. This is done more and more often using computer simulations which also study the impact on people [10-12]. Computer simulations are very good for reducing the costs of tests and barrier development and help to eliminate basic errors early at the design stage before the device is manufactured and crash-tested. If correctly validated, numerical models provide a very accurate assessment of crash intensity indicators, the damage to the vehicle and the barrier being tested.

Since they were first developed, road safety barriers have been studied at length. A lot of the research was designed to identify:

- the relation between barrier location, traffic volume, road geometry and road accidents [1,13-16],

- criteria for assessing the degree of safety barrier damage and when barriers can be reasonably repaired [17-21],

- vehicle trajectory, angle of impact and redirection [22-24],

- costs of safety barrier lifecycle depending on the frequency and scale of damage $[8,25,26]$.

The extent of damage to safety barriers is poorly researched as regards the availability of models for predicting the length of safety barrier damage. In most of the work such as [23] the extent and consequences of safety barrier damage are calculated on the basis of energy with which the car hits the safety barrier.

The paper presents a description of the tests and early results of analyses of the frequency and extent of barrier damage using an empirical sample from selected motorways and express roads in Poland.

\section{Study}

The objective of the tests is to identify the intensity of dangerous road incidents involving safety barriers and the extent of damage caused by a car as it hits a barrier. On the practical side, the tests will provide input into new methods and tools for assessing the risk of dangerous events involving cars hitting safety barriers, assessing the extent of damage to safety barriers and in a later stage for estimating the operating costs of the devices within the lifecycle of a road structure.

The work began by collecting information about Poland's national roads, assessing the risk of vehicles hitting safety barriers (Fig. 2a) and selecting sections of roads to serve as test sites. Just as the research conducted by the TRL (Transport Research Laboratory) [26], safety barriers were observed (old type barriers, new type barriers, steel, wire rope and concrete barriers) within 12 months on a selected site comprised of road sections of different categories about 3,000 km long in total (Fig. 2b) and road and road parameters were studied. The sections selected for the analysis represent a large part of the motorways $(\sim 1,200 \mathrm{~km})$, express roads $(\sim 1,000 \mathrm{~km})$ and lower class roads $(\sim 650 \mathrm{~km})($ fig. $2 \mathrm{~b})$. 

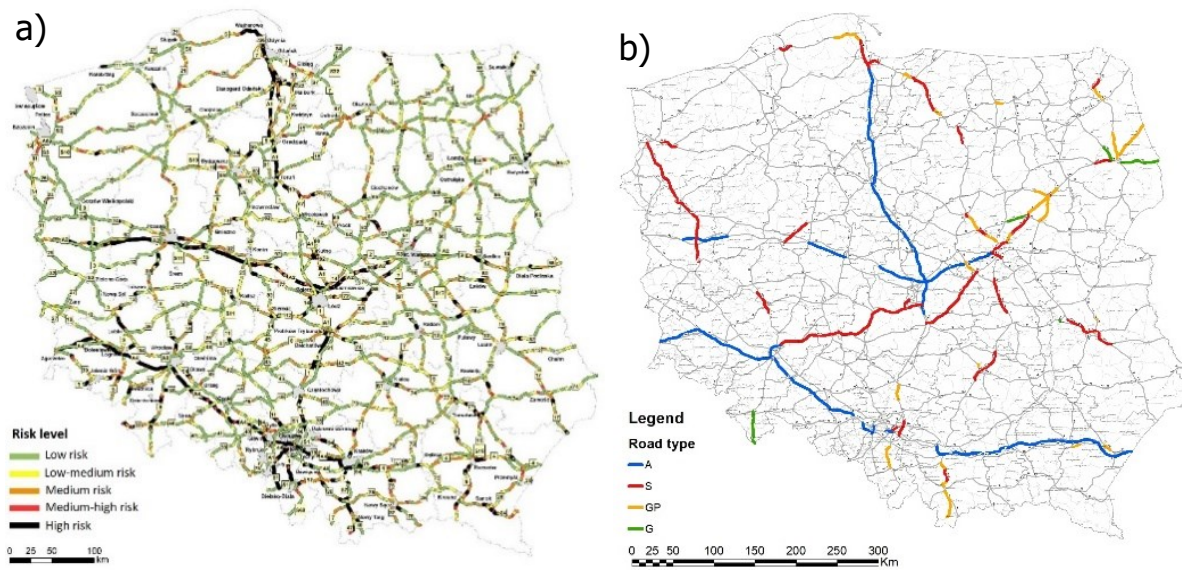

Fig. 2. Maps of the test sites: a) risk map of accidents involving hitting a safety barrier and pole b) map of road sections that make up the test site.

Once selected, the test site was supplemented with data from relevant road authorities about collisions and accidents involving road safety equipment. The data were stored in road accident, road traffic and road databases. The databases were combined and explored for the purposes of the analyses.

\section{Early study results}

The study programme included tests and analyses of the intensity and extent of damage to safety barriers. As agreed in the methodology, the work began by identifying damage on selected baseline sections. All the data and information on safety barrier damage collected so far was used to select sections which came with complete information about damage and traffic conditions. The analyses looked at incidents involving vehicles hitting a median steel barrier. Table 1 shows a sample of the data used for the initial study.

Table 1. The length of sections, traffic and number of accidents with steel median safety barriers on test sections.

\begin{tabular}{|l|c|c|c|c|c|c|c|}
\hline $\begin{array}{c}\text { Road } \\
\text { type }\end{array}$ & $\begin{array}{c}\text { Length } \\
\mathrm{L}\end{array}$ & $\begin{array}{c}\text { Section } \\
\text { number } \\
\mathrm{n}\end{array}$ & $\begin{array}{c}\text { Length } \\
\text { of } \\
\text { sections }\end{array}$ & $\begin{array}{c}\text { Minimum } \\
\text { volume } \\
\text { AADT } \min \end{array}$ & $\begin{array}{c}\text { Maximum } \\
\text { volume } \\
\text { AADT } \max \end{array}$ & $\begin{array}{c}\text { Number of } \\
\text { accidents* } \\
\text { Lacc }\end{array}$ & $\begin{array}{c}\text { Length of } \\
\text { damage* } \\
\text { Ld }\end{array}$ \\
\hline A & $6 \mathrm{~km}]$ & {$[$ number] } & {$[\mathrm{km}]$} & {$[\mathrm{veh} /$ day $]$} & {$[$ veh/day] } & {$[$ acc./year] } & {$[\mathrm{km}]$} \\
\hline S & 707 & 204 & 3.47 & 6307 & 112212 & 442 & 8.1 \\
\hline GP & 101 & 31 & 3.26 & 9224 & 59832 & 156 & 2.1 \\
\hline Sum: & $\mathbf{1 4 1 1}$ & $\mathbf{4 1 9}$ & $\mathbf{3 . 3 7}$ & $\mathbf{6 3 0 7}$ & $\mathbf{1 1 2} \mathbf{2 1 2}$ & $\mathbf{1 0 1 3}$ & $\mathbf{2 . , 8}$ \\
\hline
\end{tabular}

*accidents/damage with steel median safety barriers (estimated number of accidents/damage) A - Motorways, $\mathrm{S}$ - Express roads, GP - Main roads

The initial analyses looked at about $1,400 \mathrm{~km}$ of national roads which include motorways $(603 \mathrm{~km})$, express roads $(707 \mathrm{~km})$ and fast trunk roads $(101 \mathrm{~km})$. More than a thousand hazardous incidents were recorded on these sections with vehicles hitting the steel median barrier. The total length of safety barriers replaced by maintenance services was more than $20 \mathrm{~km}$. 
Analysis of median barrier accident intensity (Table 2) shows that the density of accidents and the average length of barrier damage as a result of a crash are the highest on fast trunk roads. Further analysis of cars hitting safety devices showed that the extent and type of damage depends on four basic factors: type of barrier (containment level), type and weight of the vehicle involved in the crash, vehicle speed upon impact and the angle of the impact into a safety barrier. The frequency of crashes and median barrier replacements depend on several basic factors: the distance between the barrier and edge of road, number of lanes (width of road) and the barrier material. The probability of a median barrier being hit increases as the distance between the barrier and edge of road decreases. The hypotheses are also confirmed in a review of international literature [22,24,27].

Table 2. Indicators of intensity and extent of damage to steel median barriers on the test site. Source: authors' work.

\begin{tabular}{|l|c|c|c|c|}
\hline \multirow{2}{*}{$\begin{array}{c}\text { Road } \\
\text { type }\end{array}$} & $\begin{array}{c}\text { Density of } \\
\text { accidents } \\
\text { Dacc }\end{array}$ & $\begin{array}{c}\text { Average length of } \\
\text { damage in a single } \\
\text { accident } \\
\text { Lp }\end{array}$ & $\begin{array}{c}\text { Density of } \\
\text { damage } \\
\text { Lo }\end{array}$ & $\begin{array}{c}\text { Share of damage } \\
\text { on a section } \\
\text { Pd }\end{array}$ \\
\cline { 2 - 5 } & {$[$ acc./km] } & {$[\mathrm{m} /$ acc. $]$} & {$[\mathrm{m} / \mathrm{km}]$} & {$[\%]$} \\
\hline A & 0.69 & 25.5 & 17.58 & 1.76 \\
\hline S & 0.62 & 18.3 & 11.46 & 1.15 \\
\hline GP & 1.54 & 13.5 & 20.79 & 2.08 \\
\hline Mean: & $\mathbf{0 . 7 2}$ & $\mathbf{2 0 . 5}$ & $\mathbf{1 4 . 7 4}$ & $\mathbf{1 . 4 7}$ \\
\hline
\end{tabular}

The work began by conducting a reliability analysis of the safety barrier damage. First, statistical distributions were used to describe the frequency and extent of damage when vehicles hit median barriers. Figure 3 shows examples of the distributions of the number of accidents on a road section and the length of damage in a single accident. The match between the distribution and empirical data was tested using the Chi-squared test.
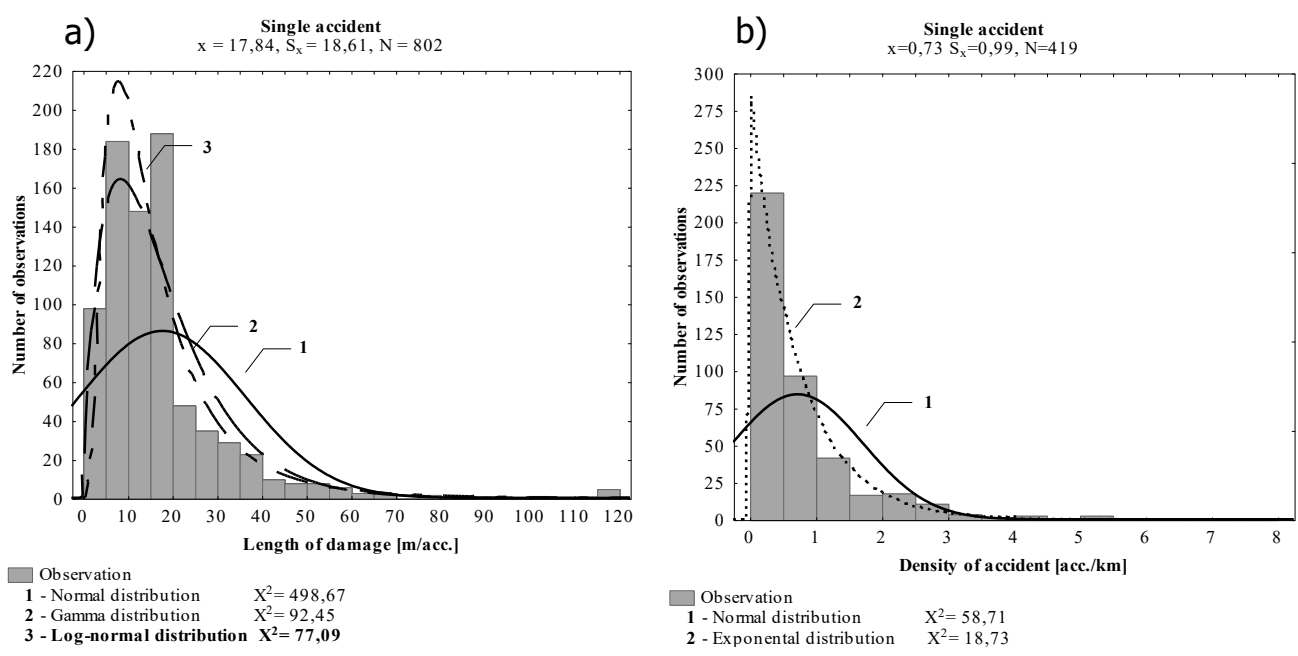

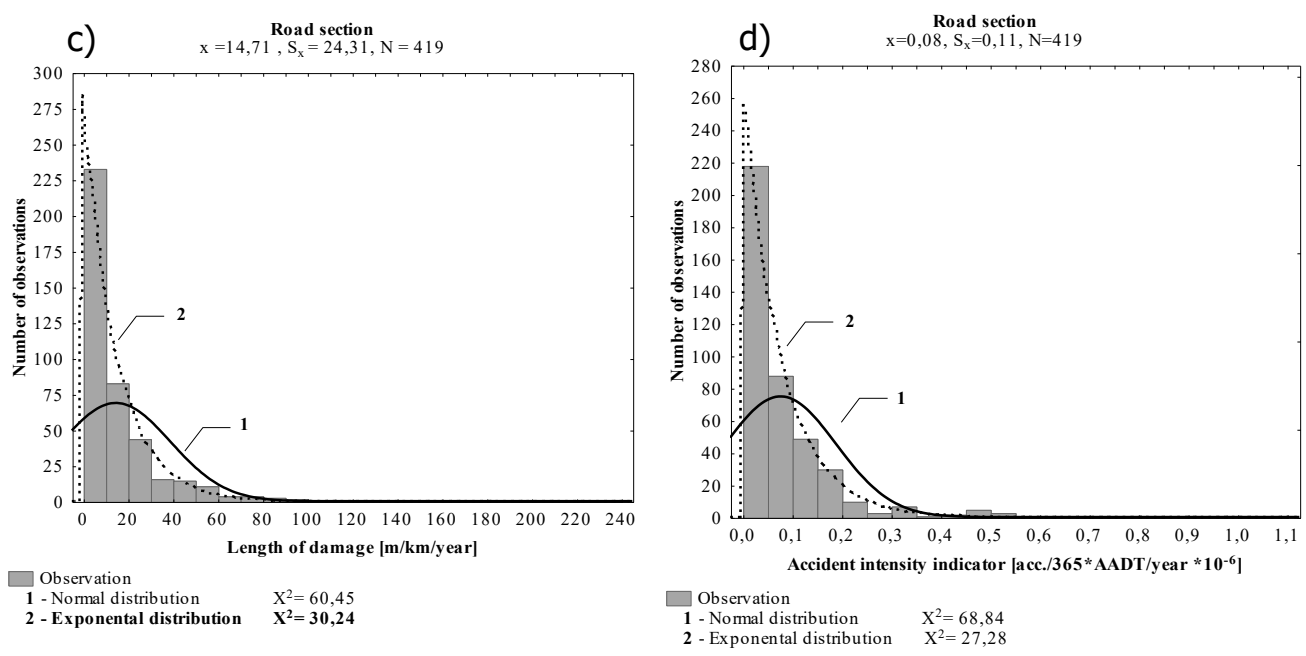

Fig. 3. Distribution of the probability density of the length of damage per a single accident and accidents on a road section. Source: authors' work.

Figure 4 shows the cumulative distribution of damage to steel median barriers for a single accident and the sum of damage on a road section. Early results of analysis for the network of national roads show that:

- on average, steel median barriers are hit by vehicles every $1.5 \mathrm{~km}$,

- within a year a $1 \mathrm{~km}$ long section has about 15 metres of steel median barriers replaced,

- a single accident damages on average 20 metres of barrier (Figure 4).

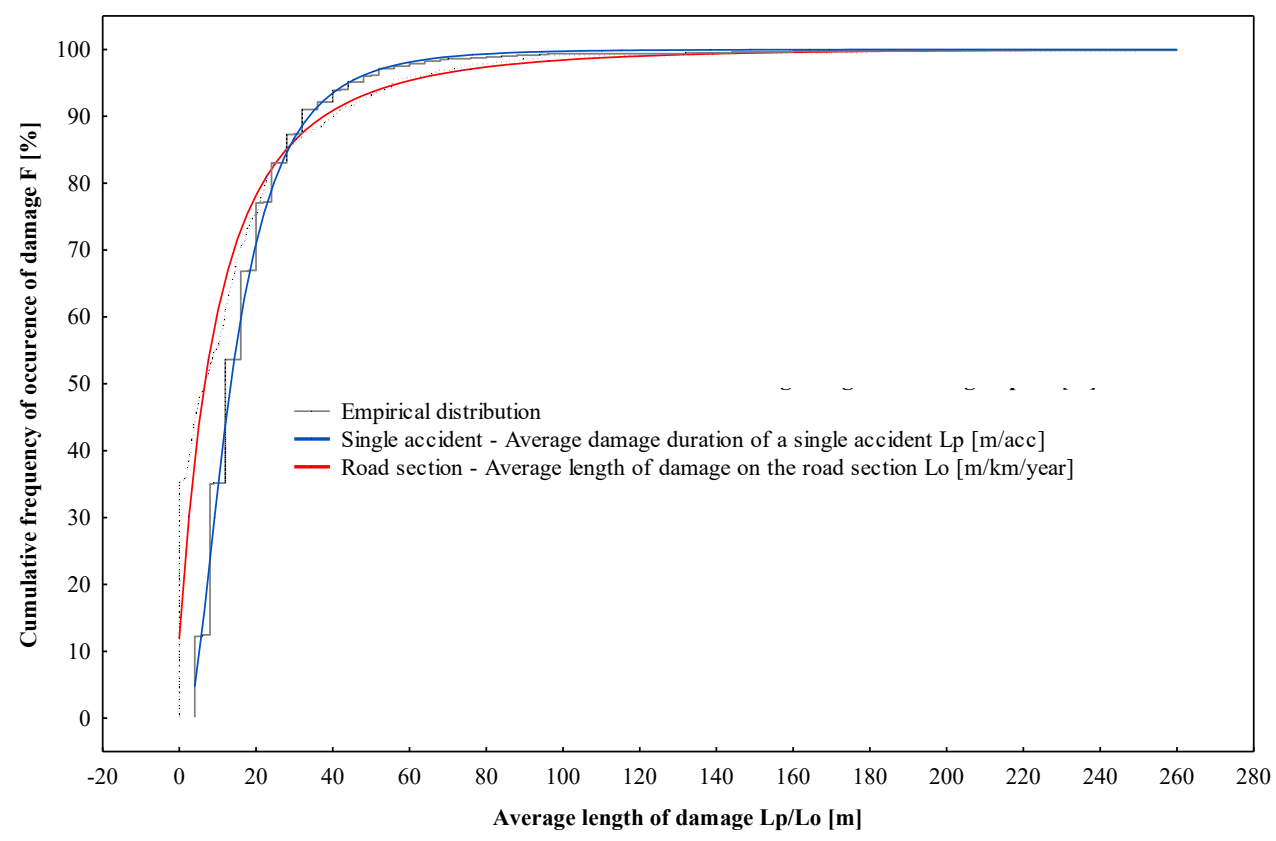

Fig. 4. Cumulative distribution of the steel road safety barrier damage. 


\section{Conclusions}

The results of the work show that the frequency and extent of damage on fast roads and motorways depend primarily on traffic volume, modal split and vehicle speeds.

The distributions of the intensity and extent of safety barrier damage will contribute to the development of more methods and tools for assessing damage to safety barriers and the risk of hazardous accidents involving safety barriers.

Tests and analyses of the frequency and extent of damage to road safety barriers are conducted under a research project for the NCBiR (National Centre for Research and Development) and the GDDKiA (General Directorate for National Roads and Motorways): RID 3B Project "Effects of time and operating conditions on the durability and functionality of road safety devices".

\section{References}

1. M. Antoniuk, Ł. Jeliński, Badanie wpływu rodzaju otoczenia drogi na liczbę i skutki niebezpiecznych zdarzeń drogowych na przykładzie dróg krajowych województwa pomorskiego (in Polish). Master Thesis (Gdansk University of Technology, 2014)

2. K. Jamroz, M. Antoniuk, L. Jelinski, K. Gronowska, Częstość i konsekwencje wypadnięcia pojazdu z drogi na przykładzie województwa pomorskiego (in Polish), Drogownictwo. 4-5 (2015)

3. K. Jamroz, K. Gronowska, M. Antoniuk, Ł. Jelinski, Identyfikacja najechań na barierę drogową na przykładzie województwa pomorskiego (in Polish), in: Semin. Forum Barier., (Cracow, 2014)

4. Ł. Jeliński, K. Jamroz, J. Jamroz, M. Antoniuk, Functionality of road safety devices identification and analysis of factors, MATEC Web Conf. 122 (2017). doi:https://doi.org/10.1051/matecconf/201712202005

5. K. Kosmowski, J. Zawalich, Zarządzanie bezpieczeństwem w złożonych obiektach i instalacjach krytycznych (in Polish), in: Model. Syst. Oceny Ryzyka i Diagnostyki Tech., pp. 167-177 (Silesian University of Technology, 2008)

6. M. Antoniuk, L. Gumińska, Ł. Jeliński, J. Wachnicka, The influence of road safety barriers on traffic safety (in Polish), Logistyka. 4 (2014). doi:10.13140/2.1.5124.9600

7. D. Cusson, Z. Lounis, L. Daigle, Durability monitoring for improved service life predictions of concrete bridge decks in corrosive environments, Comput. Civ. Infrastruct. Eng. 26 pp. 524-541 (2011). doi:10.1111/j.1467-8667.2010.00710.x

8. B. Grzyl, A. Kristowski, K. Jamroz, A. Gobis, Methods of estimating the cost of traffic safety equipment's life cycle, MATEC Web Conf. 122 (2017). doi:10.1051/matecconf/20171220 2003

9. PN-EN 1317-2 Road restraint systems, Part 2: Performance classes, impact test acceptance criteria and test methods for safety barriers including vehicle parapets (The Polish Committee for Standardization, 2010)

10. K. Jamroz, S. Burzyński, W. Witkowski, K. Wilde, G. Bagiński, Numerical methods for the assessment of bridge safety barriers, Adv. Mech. Theor. Comput. Interdiscip. Issues - 3rd Polish Congr. Mech. PCM 2015 21st Int. Conf. Comput. Methods Mech. C. 2015. (2016)

11. K. Wilde, S. Burzyński, D. Bruski, J. Chróścielewski, W. Witkowski, TB11 test for short w-beam road barrier, in: 11th Eur. LS-DYNA Conf. Salzbg. DYNAmore GmbH, (2017)

12. K. Wilde, K. Jamroz, D. Bruski, M. Budzyński, S. Burzyński, J. Chroscielewski, W. 
Witkowski, Curb-to-Barrier Face Distance Variation an a TB51 Bridge Barrier Crash

Test Simulation, Arch. Civ. Eng. 63 pp. 187-199 (2017). doi:https://doi.org/10.1515/ace-2017-0024

13. R. Elvik, The safety value of guardrails and crash cushions: A meta-analysis of evidence from evaluation studies, Pergamon. 27 pp. 523-549 (1994). doi:10.1016/00014575(95)00003-I

14. RISER, D04: Envelope of vehicle and driver response prior to collisions (Chalmers University of Technology, 2006)

15. H. Karim, R. Magnusson, M. Wiklund, Assessment of Injury Rates Associated with Road Barrier Collision, Procedia - Soc. Behav. Sci. 48 pp. 52-63 (2012). doi:10.1016/j.sbspro.2012.06.987

16. D. Hong, Y. Lee, J. Kim, W. Kim, Development of Traffic Accident Prediction Models, Proc. East. Asia Soc. Transp. Stud. 5 pp. 2046-2061 (2005)

17. AASHTO, Maintenance Manual for Roadways and Bridges. 4th Edition (American Association of State Highway and Transportation Officials, Washington D.C., 2007)

18. W.J. Fitzgerald, W-Beam Guardrail Repair: A Guide for Highway and Street Maintenance Personnel. FHWA-SA-08-002 (U.S. Department of Transportation, Federal Highway Administration, 2008)

19. D. Gabauer, H.C. Gabler, Review of Current Damage-Level Criteria for Longitudinal Barrier Repair, Transp. Res. Rec. 702 pp. 1-17 (2008)

20. H.C. Gabler, D.J. Gabauer, C.E. Hampton, Criteria for Restoration of Longitudinal Barriers. NCHRP Report 656 (Transportation Research Board, 2010)

21. G. Fredriksson, H.G. Holmen, The ageing of safety barriers. Functional limits for safety barriers that deviate from the nominal in height and/or perpendicular position. Report 1301-1 (Trafikverket, 2013)

22. RISER, D06: European best practice for roadside design: Guidelines for roadside infrastructure on new and existing roads (Chalmers University of Technology, 2005)

23. K.K. Mak, D.L. Sicking, Roadside Safety Analysis Program (RSAP) - Engineer's Manual. NCHRP Report 492 (Transportation Research Board, 2012)

24. J. McCullah, D. Gray, Environmentally Sensitive Channel- and Bank-Protection Measures. NCHRP Report 544 (Transportation Research Board, 2005)

25. H. Karim, R. Magnusson, K. Natanaelsson, Life-Cycle Cost Analyses for Road $\begin{array}{llllll}\text { Barriers, J. Transp. } & \text { Eng. } 138 \text { pp. } & 830-851 & \text { (2012). }\end{array}$ doi:https://doi.org/10.1061/(ASCE)TE.1943-5436.0000391

26. G.L. Williams, Whole Life Cost-Benefit Analysis for Median Safety Barriers. Project report PPR279 (TRL, 2007)

27. B.R. Hammonds, R. Troutbeck, Crash Test Outcomes for Three Generic Barrier Types, in: 25th ARRB Conf. - Shap. Futur. Link. Policy, Res. Outcomes, (Perth, Australia, 2012) 